\title{
PERFORMANCE STUDY OF IMITATED SYNGAS IN A DUAL-FUEL COMPRESSION IGNITION DIESEL ENGINE
}

\author{
Bahaaddein K.M. Mahgoub, S.A. Sulaiman and Z.A. Abdul Karim \\ Department of Mechanical Engineering \\ Universiti Teknologi PETRONAS \\ 31750 Tronoh, Perak, Malaysia \\ Phone: +605-365-4055; Fax: +605-3654090 \\ Email: m.bahaa02@uofk.edu
}

\begin{abstract}
Operating engines fueled by syngas and diesel is an available renewable option to avert concerns related to the supply of petroleum and the environment. But the use of syngas in a compression ignition (CI) diesel engine leads to a reduction in the power output because of its lower heating value compared with the $100 \%$ diesel mode. Furthermore, it is not easy to evaluate the performance of real syngas due to the varying gas content when inducted into a CI diesel engine. In this study, a single-cylinder, two-stroke, naturally aspirated CI diesel engine was operated with imitated syngas as the primary fuel in dual-fuel mode. The objective of this study is to investigate the effect of syngas composition on the performance of a dual-fuel engine running at different engine speeds $(1200,2000,3000 \mathrm{rpm})$. The impact of engine speed on the performance of syngas in the dual-fuel CI diesel engine was examined at various diesel replacement ratios (DR\%). Composition $\mathrm{C}$ showed the best results for engine performance compared to other compositions.
\end{abstract}

Keywords: Engine performance; syngas; dual fuel; compression ignition engine.

\section{INTRODUCTION}

Operation of the internal combustion engine with syngas as an alternative fuel for diesel is the focus of this study. Syngas is a gaseous fuel that can be produced from the process of biomass gasification [1]. Syngas has a low-density energy and low calorific value compared to diesel $[2,3]$. Recently, researchers have made many activities to look for alternative fuels due to the depletion of petroleum fuel and the instability of its prices [4-7]. Syngas is considered to be a renewable source of energy for the future because of the availability of the raw material, biomass, which is used in the gasification process in different amounts almost all over the world. Syngas has the ability to substitute fossil fuel in a compression ignition (CI) diesel engine under dual-fuel mode [8]. The advantage of operating CI engines with syngas to generate power, could be exploited when a pilot diesel is injected into the engine under dual-fuel operation mode and the mixture is lean [9]. Under operation of a CI engine in dual-fuel mode, the air is mixed with gaseous fuel and the mixture is compressed as in a normal diesel engine. The mixture would not ignite automatically because the air/gas mixture auto-ignition temperature is high. Accordingly, a small amount of diesel fuel is suddenly infused and ignited at the end of the compression phase which boots the mixture combustion $[3,4$, 10]. The main benefit of running the engine in dual-fuel mode is the use of two types of fuel, both of which are combustible. Favorable energy and environmental protection 
could be attained with the operation of a CI engine using gaseous fuel in dual-fuel mode. In addition, the engine could be easily switched from dual-fuel mode to diesel mode at any time.

Different engines have been operated with syngas as a fuel [1, 11, 12], but the ignition system of most of these engines was spark ignition (SI). An engine with an SI combustion system is not considered appropriate for syngas fuel under operation of high load; this is because achieving stable combustion is not possible owing to the fluctuation of the syngas components. Moreover, syngas is not like gasoline and natural gas fuels which have high-energy-density, so the degradation of power in cases using syngas is widespread. The operational behavior of a diesel engine running in dual-fuel mode on syngas from the gasification of coffee husks was examined by Krishna and Kumar [13]. A value of $31 \%$ only was recorded as the higher rate of diesel reinstatement. In a few previous research studies, syngas was used as a fuel for CI engines. Most of the experiments were carried out to ascertain the performance and emissions of dual-fuel syngas-powered engines. A producer gas was used by Nayak et al. as the primary fuel for a single cylinder dual fuel diesel engine. Jatropha oil and Jatropha oil methyl ester were preheated in order to reduce their viscosity and then injected into the engine to demonstrate its performance and emission characteristics. Operating the engine with diesel and producer gas was considered as a baseline and showed improved performance results at various engine load conditions, whereas Jatropha oil and Jatropha oil methyl ester with producer gas showed very close results. It was concluded that the diesel fuel can be successfully replaced by preheated Jatropha oil-producer gas and Jatropha oil methyl ester-producer gas with little modification.

Mahgoub et al. [14] used a controllable mixture and the characteristics of simulated syngas in a dual-fuel CI diesel engine. Three syngas mixtures were used to run a naturally aspirated dual-fuel CI diesel engine. The performance of the syngas was determined when the engine operated at a speed of $2000 \mathrm{rpm}$. A comparison was made for the performance of the engine dually fueled with a syngas/diesel mixture and with liquid diesel alone. It was concluded that the brake power output and thermal efficiency were reduced with the use of syngas as a fuel in the naturally aspirated dual-fuel CI diesel engines. Moreover, the performance of the engine was affected differently by the variations in syngas composition. An investigation was made by Roy et al. [15] into the influence of some liquid fuel injection parameters on the performance and exhaust emissions of dually fueled producer gas/diesel engines in supercharging mode. The engine was tested to be used as a co-generation engine and its power output was an important parameter. Experiments were performed to optimize the injection timing, injection pressure and injection quantity for maximization of the engine power. At constant injection pressures, there was an optimum amount of pilot injection quantity for which maximum engine power was developed. Above or below that, the amount of engine power decreased. Higher injection pressures generally showed better results than the lower ones. From the above-mentioned studies, it can be implied that dual-fuel combustion, using producer gas from the biomass gasification process and diesel as the fuel for naturally aspirated CI engines, leads to lower brake thermal efficiency with higher brake specific fuel consumption. However, the performance and emissions of the dually fueled syngas/diesel CI engines are affected by some of the engine operating parameters and variations in the syngas fuel composition. The objective of this study is to investigate the effect of engine speed on the performance of a naturally aspirated CI engine running on diesel and different compositions of imitated syngas in dual-fuel mode. 


\section{EXPERIMENTAL SET-UP}

The engine which was used in this study was a naturally aspirated, two-stroke, singlecylinder diesel engine with rated power of $5 \mathrm{hp}$. The engine performance was investigated in terms of no load. Three mixtures of simulated syngas were used to operate the engine at speeds of 1200, 2000, and $3000 \mathrm{rpm}$ for various ratios of diesel replacement. Table 1 shows the engine specifications used.

Table 1. Engine technical data.

\begin{tabular}{ll}
\hline Engine type & Single cylinder \\
Bore $(\mathrm{mm})$ X Stroke (mm) - CR & 78 X 67 - 17.6:1 \\
Piston displacement (Liter) & 0.32 \\
Power output (kW) & 4 @ 3600 rpm \\
\hline
\end{tabular}

Three compositions of syngas were simulated to represent the product of the biomass gasification process. Composition A was selected according to the typical range of syngas composition as reported by Ciferno and Marano [16]. Compositions B and $\mathrm{C}$ were decided based on previous studies $[17,18]$ and they were close to real conditions. The selected syngas compositions are given in Table 2.

Table 2. Properties of selected syngas.

\begin{tabular}{lccccccc}
\hline & $\mathrm{N}_{2}$ & $\mathrm{CO}_{2}$ & $\mathrm{CO}$ & $\mathrm{H}_{2}$ & $\mathrm{CH}_{4}$ & $\mathrm{LHV}(\mathrm{kJ} / \mathrm{kg})$ & $\rho\left(\mathrm{kg} / \mathrm{m}^{3}\right)$ \\
\hline Composition A & 49 & 12 & 25 & 10 & 4 & 4726.19 & 1.1 \\
Composition B & 51 & 6 & 22 & 18 & 3 & 5418.4 & 0.94 \\
Composition C & 38 & 8 & 29 & 19 & 6 & 7444.13 & 0.93 \\
\hline
\end{tabular}

The engine speed and torque were measured using a TD115 hydraulic dynamometer. Further elements such as a gas mixing device, one-way valve, pressure regulator, flow meter, and Teflon tube etc. were attached to the diesel engine, so that the engine could be used to run in only liquid fuel mode or on the diesel/syngas mixture under dual-fuel operation. The experimental rig that was used to deliver the syngas to the engine intake manifold was described in a previous work by Mahgoub et al. [14]. The rig consisted of gas cylinders which contained five types of gas representing the composition of syngas. Pressure regulators were connected to all the gas cylinders in order to reduce the gas pressure from 200 bars and deliver the gases to the engine intake manifold at a pressure of 1 bar. The required syngas compositions were obtained by controlling the flow of each gas through flow meters and controllers. A fabricated mixing device was used to mix the five different gases. Then, the gaseous mixture was premixed with air before entering the engine air intake manifold. The schematic of the syngas supply system is shown in Figure 1.

The engine was run first on diesel only at a constant speed of $1200 \mathrm{rpm}$. Then, a known amount of imitated syngas was introduced through the air intake valve. The speed of the engine increased with the increase in syngas amount because more fuel was available inside the combustion chamber. Then the amount of diesel was controlled and reduced through the engine rack in order to get the engine speed back to $1200 \mathrm{rpm}$. More syngas was added and the diesel flow rate reduced conversely in order to obtain different ratios of diesel displacement. Engine performance measurements were recorded for each diesel replacement ratio at $1200 \mathrm{rpm}$. The test was then repeated at 
different engine speeds of 2000 and $3000 \mathrm{rpm}$ to study the performance of syngas at low, medium and high engine speeds. The equations and measurements that were used to determine the engine performance were previously described in the work of Mahgoub et al. [14].

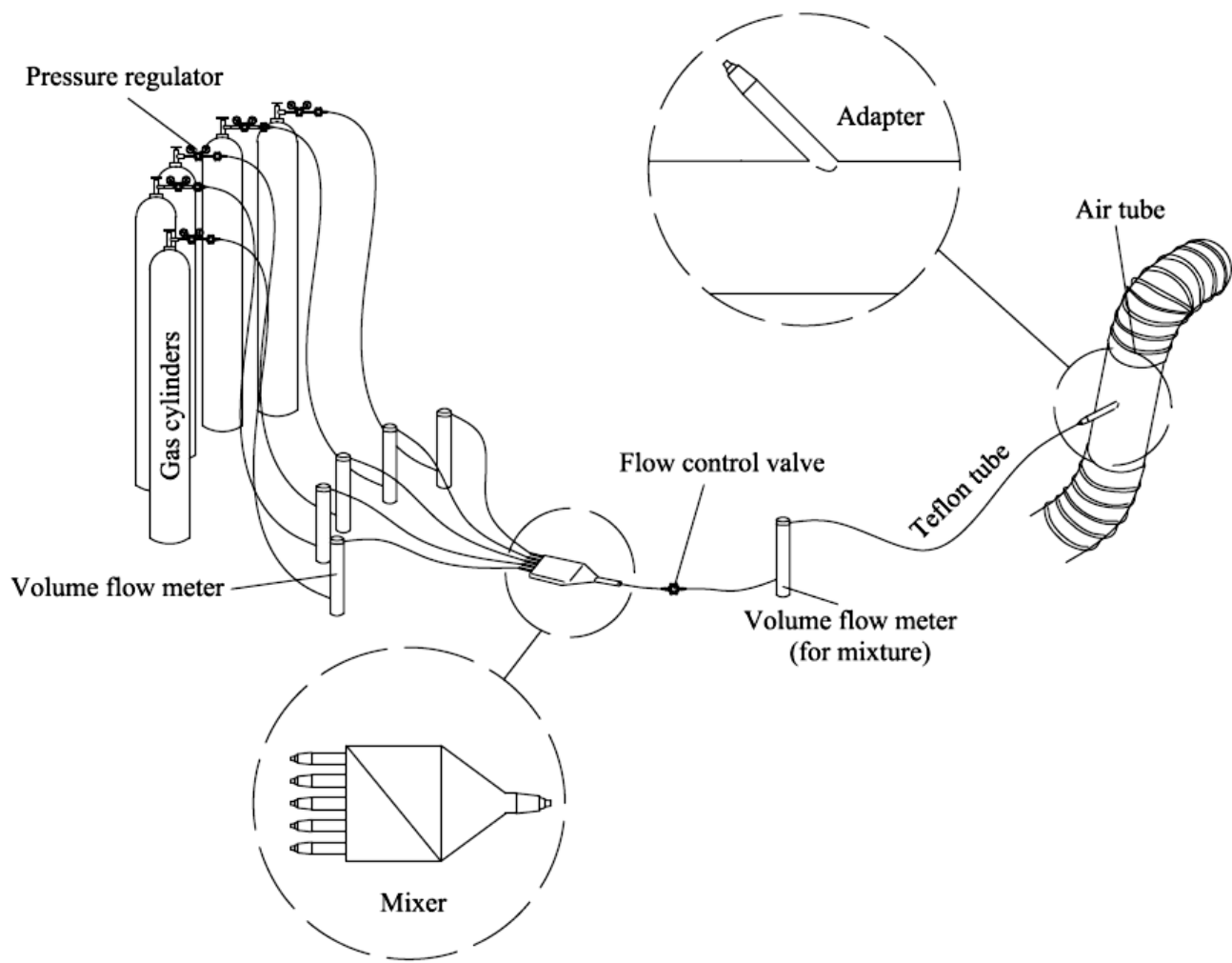

Figure 1. Schematic of syngas supply system [14].

\section{RESULTS AND DISCUSSION}

The syngas performance was compared with the performance of diesel at various engine speeds. The study was undertaken in order to evaluate engine performance for diesel and three compositions of syngas and the ability to replace diesel. Measuring the exhaust temperature is useful for a better understanding of engine processes. The exhaust temperature gives information about the amount of heat generated in the cylinder wall which affects engine exhaust emissions. Figure 2 shows the engine exhaust temperature for various ratios of diesel replacement at various engine speeds. It can be seem that the diesel replacement ratio decreases with increases in engine speed because the diesel flow rate increases for the same flow rate of syngas. Similar trends are observed for all syngas compositions. However, Composition $\mathrm{C}$ showed a further reduction in exhaust temperature because it was able to operate at high diesel replacement ratios. It was also observed that when the amount of syngas increased the exhaust gas temperature decreased for all examined engine speeds. Composition $\mathrm{C}$ has the highest exhaust temperature at all engine speeds because it contains high amounts of $\mathrm{CO}$ and $\mathrm{CH}_{4}$, while Compositions $\mathrm{A}$ and $\mathrm{B}$ show lower exhaust temperatures due to decreases in carbon monoxide and methane content, respectively. The exhaust gas temperature decreases gradually at low engine speed and decreases faster as the engine speed increases because more fuel flows into the engine cylinders at the high engine speed which leads to a high flame temperature. 


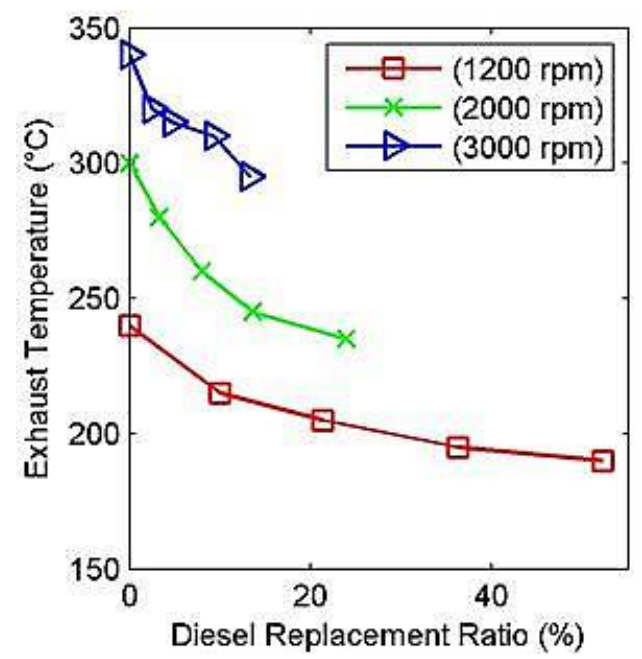

(A) $49 \% \mathrm{~N}_{2}-12 \% \mathrm{CO}_{2}-25 \% \mathrm{CO}-10 \% \mathrm{H}_{2}-4 \% \mathrm{CH}_{4}$

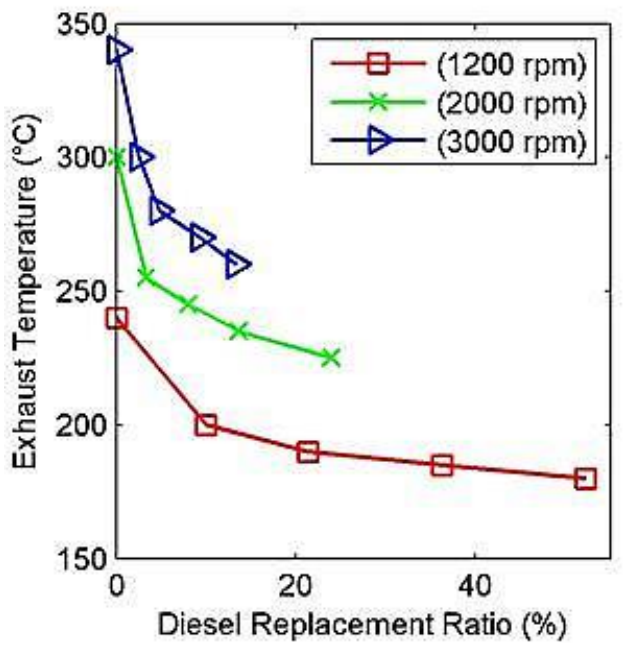

(B) $51 \% \mathrm{~N}_{2}-6 \% \mathrm{CO}_{2}-22 \% \mathrm{CO}-18 \% \mathrm{H}_{2}-3 \% \mathrm{CH}_{4}$

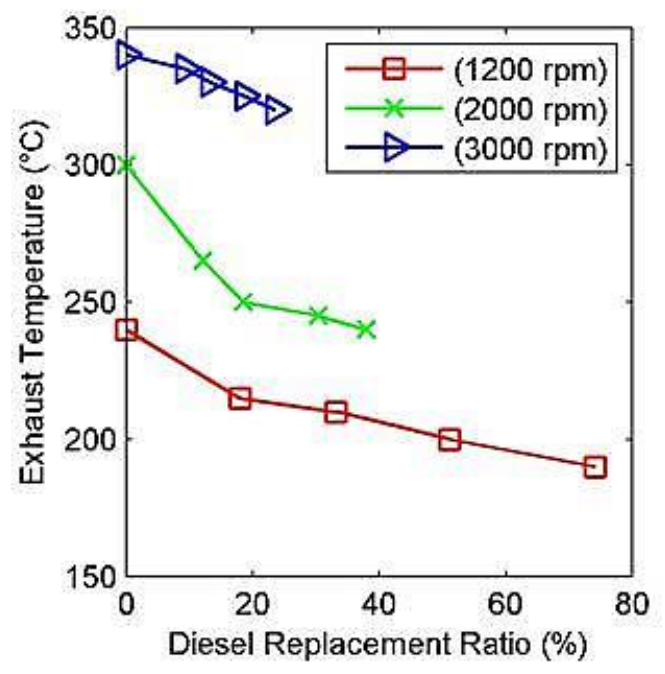

(C) $38 \% \mathrm{~N}_{2}-8 \% \mathrm{CO}_{2}-29 \% \mathrm{CO}-19 \% \mathrm{H}_{2}-6 \% \mathrm{CH}_{4}$

Figure 2. Exhaust temperature vs diesel replacement ratio at various engine speeds.

Figure 3 shows the engine brake power output for various ratios of diesel replacement at various engine speeds. The engine brake power output increases when the engine speed increases for all syngas compositions. This is because more fuel flows into the engine cylinder at high engine speeds leading to higher power output. A similar trend of engine brake power was noted for all syngas compositions at the various engine speeds. Lower brake power was obtained when the engine operated on syngas/diesel dual fuel as compared with the operation in pure diesel mode $(\mathrm{DR} \%=0)$, this is because syngas has a lower heating value than diesel. The brake power was clearly improved with the use of Composition $\mathrm{C}$ because of the high presence of $\mathrm{CO}$ and $\mathrm{CH}_{4}$, followed by Compositions $\mathrm{B}$ and $\mathrm{A}$. A higher amount of diesel could be replaced with the operation of the engine using Composition C at a speed of $1200 \mathrm{rpm}$ compared with other compositions, as shown in Figure 3(c). This was largely because Composition C had the lowest density of all compositions used so facilitating the entrance of more air to improve the combustion process. 


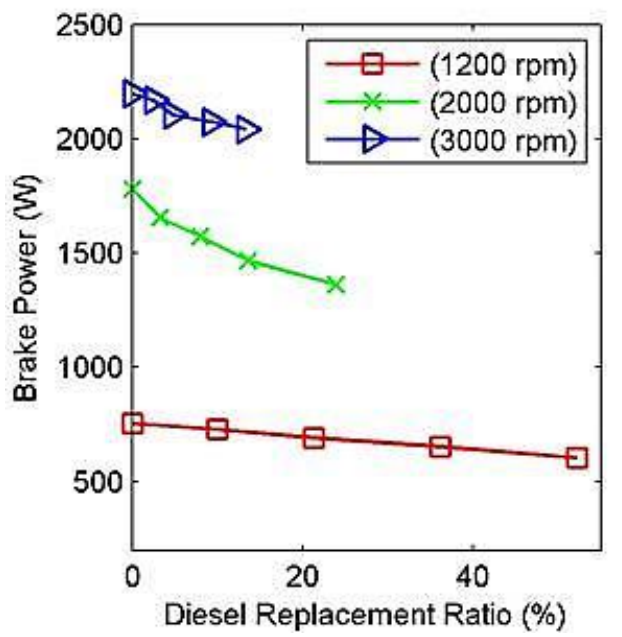

(A) $49 \% \mathrm{~N}_{2}-12 \% \mathrm{CO}_{2}-25 \% \mathrm{CO}-10 \% \mathrm{H}_{2}-4 \% \mathrm{CH}_{4}$

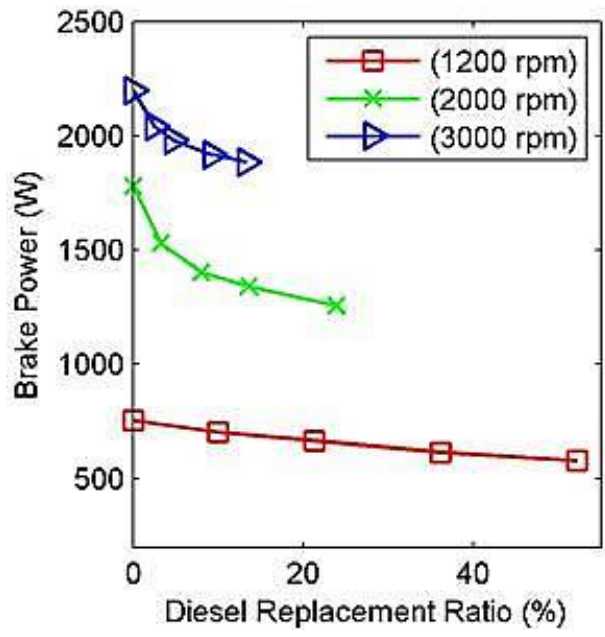

(B) $51 \% \mathrm{~N}_{2}-6 \% \mathrm{CO}_{2}-22 \% \mathrm{CO}-18 \% \mathrm{H}_{2}-3 \% \mathrm{CH}_{4}$

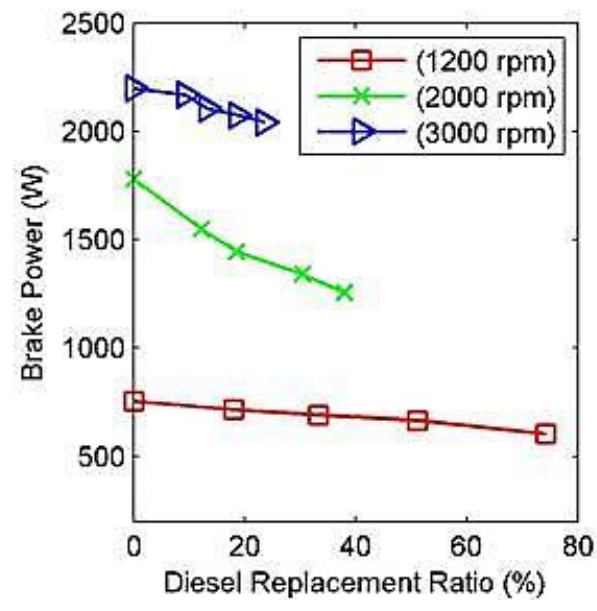

(C) $38 \% \mathrm{~N}_{2}-8 \% \mathrm{CO}_{2}-29 \% \mathrm{CO}-19 \% \mathrm{H}_{2}-6 \% \mathrm{CH}_{4}$

Figure 3. Brake power vs diesel replacement ratio at various engine speeds.

The brake specific fuel consumption for various ratios of diesel replacement at various engine speeds is shown in Figure 4. The total brake specific fuel consumption was estimated from the brake power output of the engine and the measured mass flow rate of the fuels. When the engine operated at a speed of $2000 \mathrm{rpm}$, the brake specific fuel consumption had minimum values and increased before and after this speed for all syngas compositions. This was because of the longer duration of the heat transfer from the working fluid to the engine cylinder walls at the low engine speed. At the high engine speed, the friction losses led to a decrease in brake torque and an increase in brake specific fuel consumption (BSFC). Although the highest fuel consumption is shown in Figure 4 to result from Compositions A and B at $3000 \mathrm{rpm}$, the engine had the lowest specific fuel consumption for Composition $\mathrm{C}$ at $3000 \mathrm{rpm}$. This was because the engine was running with Composition $\mathrm{C}$ rather than the other compositions in leaner mode. Considering the fact that the syngas heating value was lower than that of diesel, it could be that higher fuel consumption would be needed when using syngas for combustion leading to high brake specific fuel consumption. 


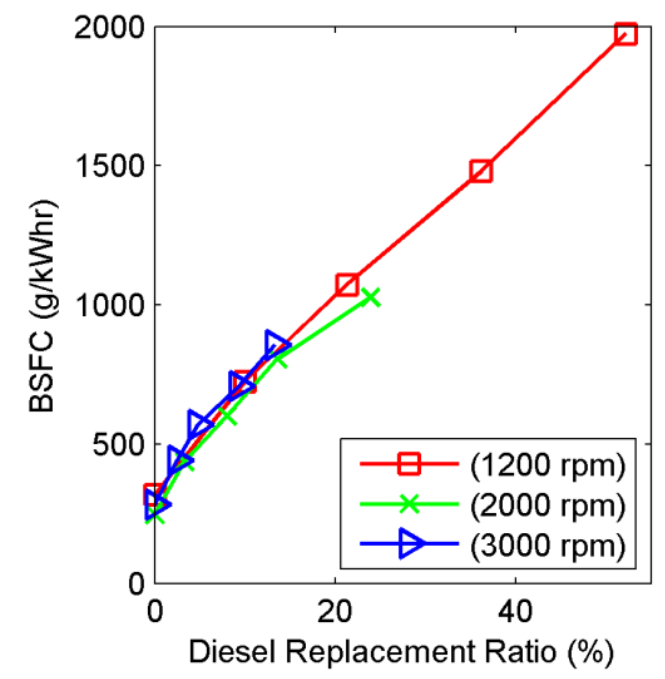

(A) $49 \% \mathrm{~N}_{2}-12 \% \mathrm{CO}_{2}-25 \% \mathrm{CO}-10 \% \mathrm{H}_{2}-4 \% \mathrm{CH}_{4}$

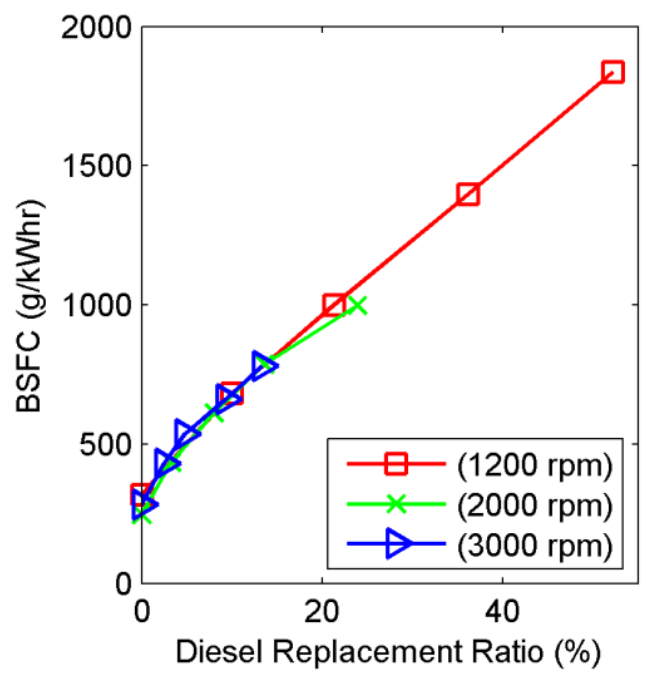

(B) $51 \% \mathrm{~N}_{2}-6 \% \mathrm{CO}_{2}-22 \% \mathrm{CO}-18 \% \mathrm{H}_{2}-3 \% \mathrm{CH}_{4}$

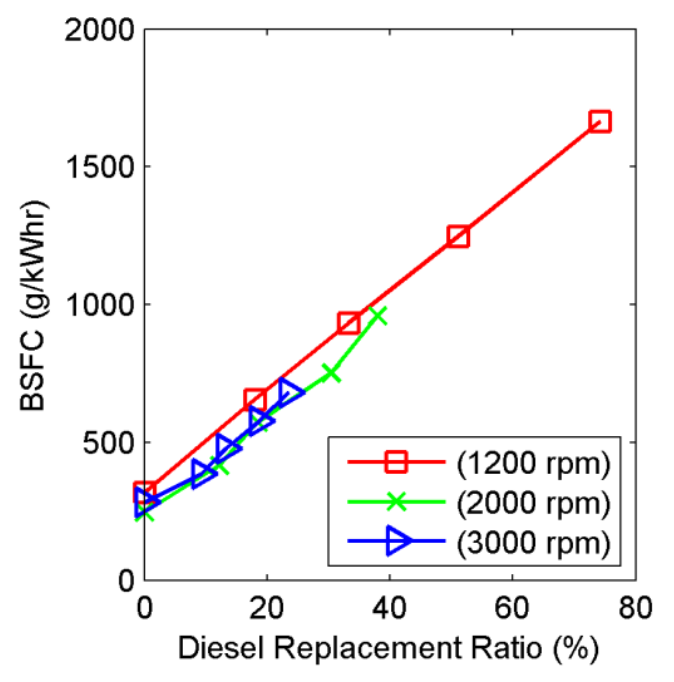

(C) $38 \% \mathrm{~N}_{2}-8 \% \mathrm{CO}_{2}-29 \% \mathrm{CO}-19 \% \mathrm{H}_{2}-6 \% \mathrm{CH}_{4}$

Figure 4. BSFC Vs diesel replacement ratio at various engine speeds.

The most suitable parameter to compare the performance of different fuels is the brake thermal efficiency because it includes the fuel consumption alongside its heating value. Figure 5 shows the brake thermal efficiency for various ratios of diesel replacement at various engine speeds. Brake thermal efficiency increases with the increase in engine speed up to $2000 \mathrm{rpm}$ which corresponds to the minimum brake specific fuel consumption, as shown in Figure 4, for all syngas compositions. Beyond $2000 \mathrm{rpm}$ it decreased due to the increase in engine friction losses. The brake thermal efficiency also increased as the mixture became very rich because the mixture properties approach those of ideal gases. Therefore, the engine showed the highest values of brake thermal efficiency at $2000 \mathrm{rpm}$ due to the operation of the engine with a rich mixture inside the combustion chamber, as will be discussed in the following section. Operating engines in syngas dual-fuel mode generally leads to low thermal efficiencies because of the presence of $\mathrm{CO}_{2}$ in the syngas composition [19]. Brake thermal efficiencies for Compositions $\mathrm{A}$ and $\mathrm{B}$ reduced faster at the higher engine speed as compared to 
Composition $\mathrm{C}$ because of the high $\mathrm{CO}$ and $\mathrm{CH}_{4}$ content in Composition $\mathrm{C}$. A similar reduction in brake thermal efficiency was obtained by Shrivastava et al. [20] when a CI engine was coupled with a downdraft gasifier running in dual-fuel mode.

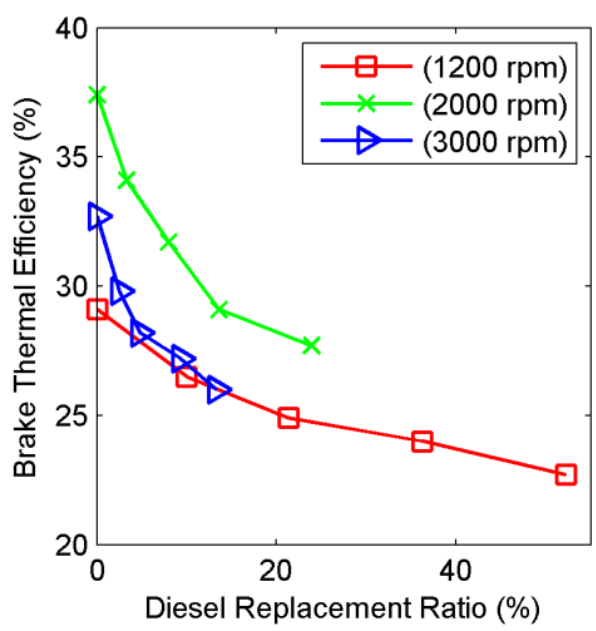

(A) $49 \% \mathrm{~N}_{2}-12 \% \mathrm{CO}_{2}-25 \% \mathrm{CO}-10 \% \mathrm{H}_{2}-4 \% \mathrm{CH}_{4}$

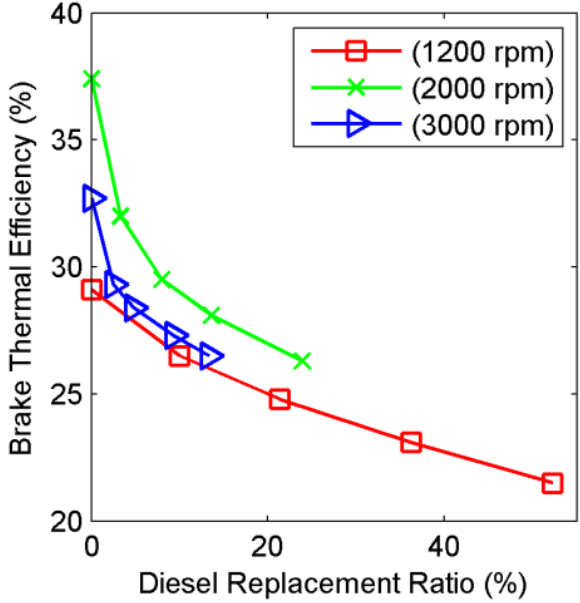

(B) $51 \% \mathrm{~N}_{2}-6 \% \mathrm{CO}_{2}-22 \% \mathrm{CO}-18 \% \mathrm{H}_{2}-3 \% \mathrm{CH}_{4}$

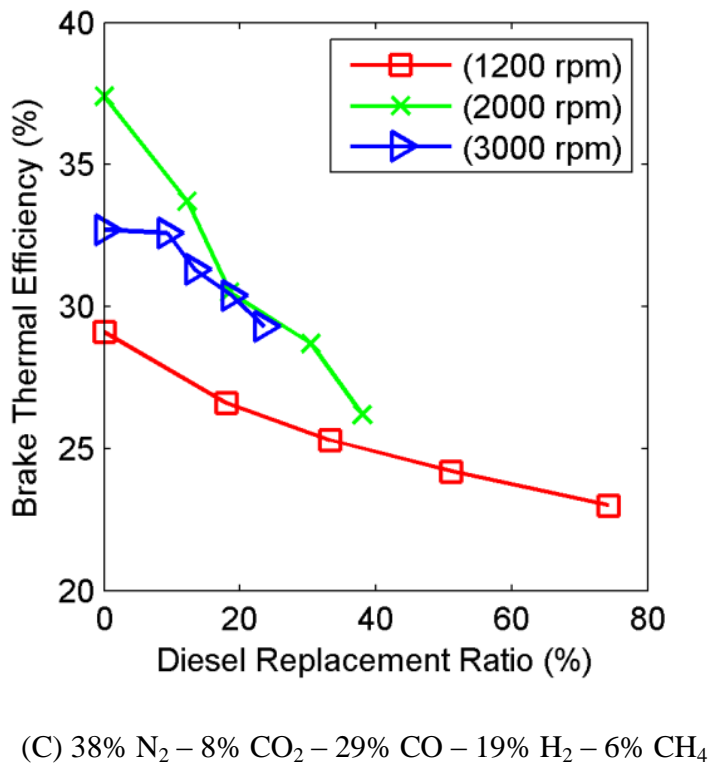

Figure 5. Brake thermal efficiency vs diesel replacement ratio at various engine speeds.

The fuel air equivalence ratio $\Phi$ is the ratio of the actual fuel/air ratio to the stoichiometric ratio. It is a very useful parameter in defining a mixture composition and indicating the quality of the combustion [21]. Figure 6 depicts the fuel air equivalence for various ratios of diesel replacement at various engine speeds. The fuel air equivalence ratio increased with the increase in engine speed due to the increase in the fuel delivered to the engine cylinder which led to an increase in the actual fuel air ratio. The fuel air equivalence ratio increased with the increase in diesel replacement ratio for all syngas compositions at all engine speeds because of the replacement of the air by syngas which led to an increase in the actual ratio of fuel to the air, making the combustion richer. The fuel air equivalence ratio at $2000 \mathrm{rpm}$ for all syngas 
compositions is shown to be at its highest due to the operation of the engine at its maximum torque value which occurs at $2000 \mathrm{rpm}$. The minimum fuel air equivalence ratio was observed in dual-fuel mode at $3000 \mathrm{rpm}$ because the rate of air flow increased for the same rate of syngas flow causing leaner combustion.

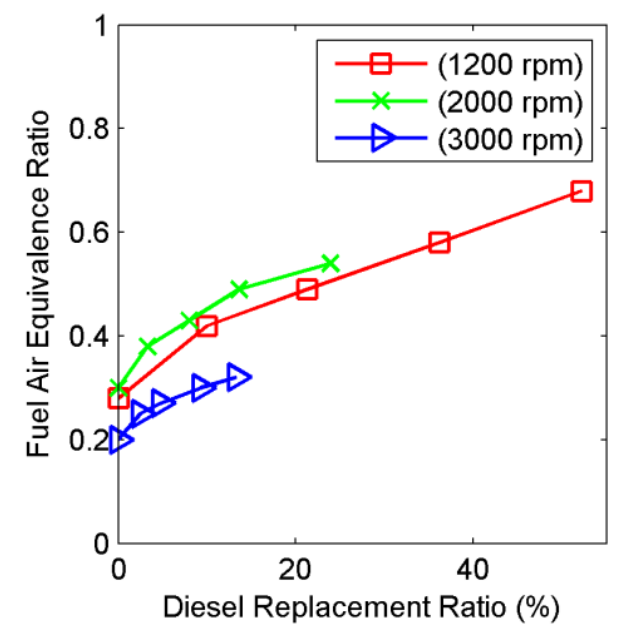

(A) $49 \% \mathrm{~N}_{2}-12 \% \mathrm{CO}_{2}-25 \% \mathrm{CO}-10 \% \mathrm{H}_{2}-4 \% \mathrm{CH}_{4}$

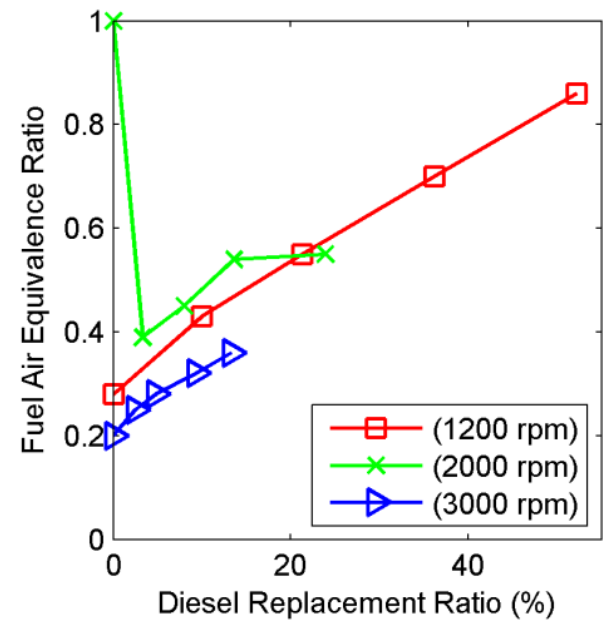

(B) $51 \% \mathrm{~N}_{2}-6 \% \mathrm{CO}_{2}-22 \% \mathrm{CO}-18 \% \mathrm{H}_{2}-3 \% \mathrm{CH}_{4}$

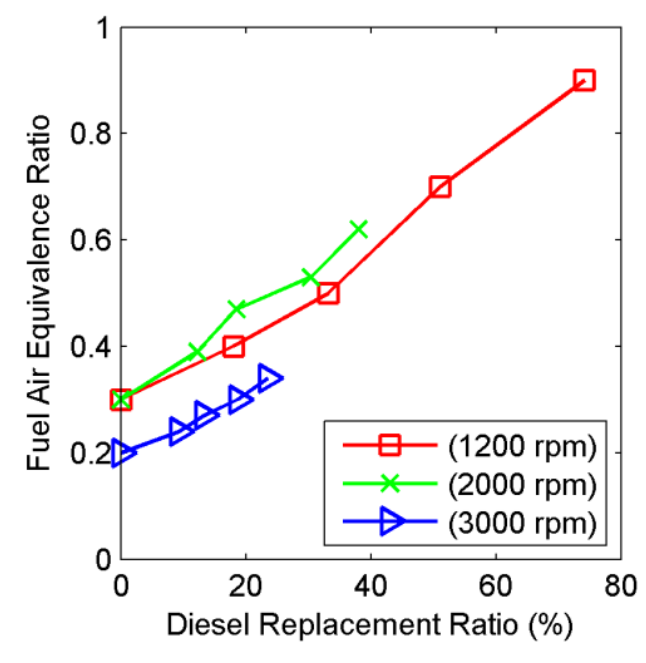

(C) $38 \% \mathrm{~N}_{2}-8 \% \mathrm{CO}_{2}-29 \% \mathrm{CO}-19 \% \mathrm{H}_{2}-6 \% \mathrm{CH}_{4}$

Figure 6. Fuel air equivalence ratio vs diesel replacement ratio at various engine speeds.

The volumetric efficiency for various ratios of diesel replacement at various engine speeds is shown in Figure 7. Volumetric efficiency is known as the amount of air drawn into the engine cylinder, or precisely the actual ratio of air mass flow to the ideal flow. In the present study, syngas/air was induced inside the engine cylinder. It is shown that high engine speed led to high volumetric efficiency because of the resulting high vacuum at the air intake port and consequently the high air flow rate inside the engine cylinder. Syngas is less dense than air and hence, light syngas displaced some air flow sucked into the cylinder in dual-fuel mode. This resulted in volumetric efficiency reduction at all engine speeds. The volumetric efficiency is further decreased when the syngas flow rate is increased. Similar results were obtained by Saha et al. [22] when three different volumetric compositions of syngas were examined in diesel engines in dual-fuel mode. Under dual-fuel operation, Composition $\mathrm{C}$ showed the highest 
volumetric efficiency due to its lower density compared to other compositions. At maximum engine speed, the maximum volumetric efficiency was recorded as $92.1 \%$ with Composition $\mathrm{C}$ for dual-fuel mode. This is due to the availability of a high amount of air at maximum engine speed, as interpreted from the fuel air equivalence ratio in Figure 6.

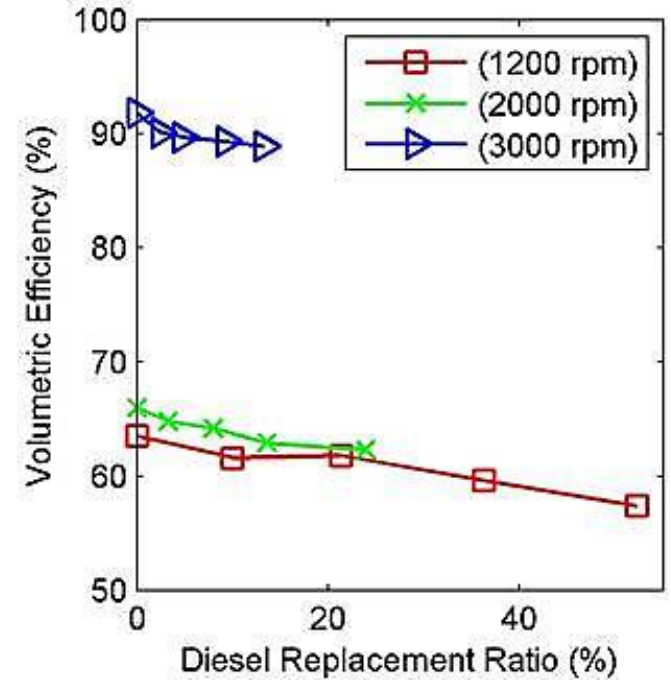

(A) $49 \% \mathrm{~N}_{2}-12 \% \mathrm{CO}_{2}-25 \% \mathrm{CO}-10 \% \mathrm{H}_{2}-4 \% \mathrm{CH}_{4}$

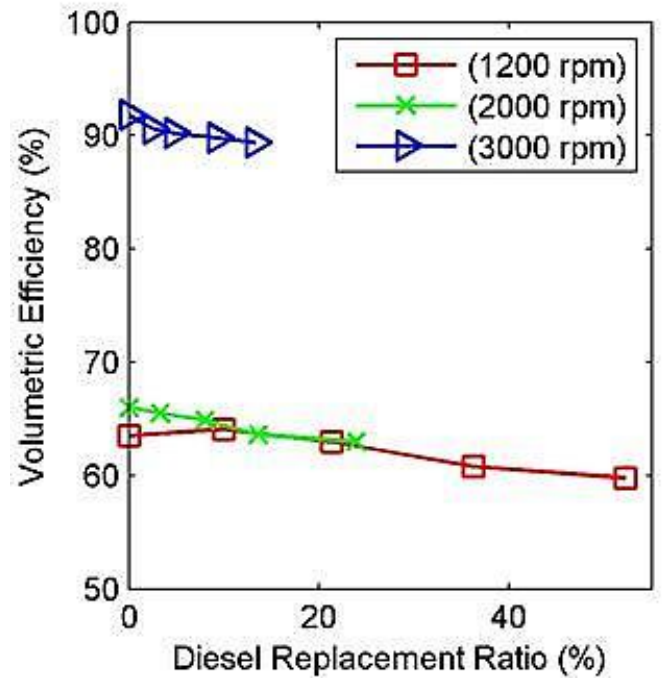

(B) $51 \% \mathrm{~N}_{2}-6 \% \mathrm{CO}_{2}-22 \% \mathrm{CO}-18 \% \mathrm{H}_{2}-3 \% \mathrm{CH}_{4}$

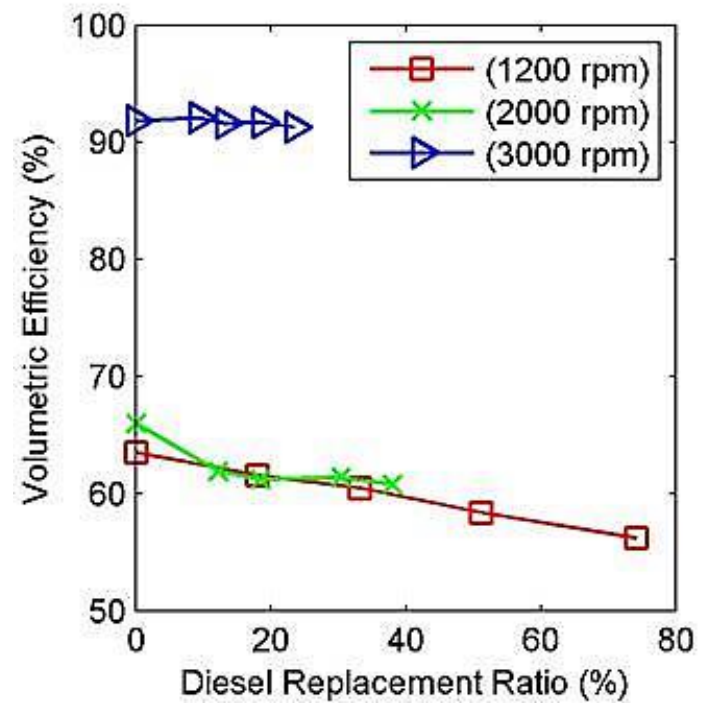

(C) $38 \% \mathrm{~N}_{2}-8 \% \mathrm{CO}_{2}-29 \% \mathrm{CO}-19 \% \mathrm{H}_{2}-6 \% \mathrm{CH}_{4}$

Figure 7. Volumetric efficiency Vs diesel replacement ratio at various engine speeds.

\section{CONCLUSIONS}

In this work, an experimental test was conducted to study the performance of syngas in a single-cylinder CI diesel engine under dual-fuel mode at various engine speeds. The engine was properly operated under syngas/diesel dual-fuel operation and its basic configuration was maintained as in its original setting. From analysis of the experimental data and comparison between normal diesel and syngas dual-fuel 
operations, the following could be concluded:

- Dual-fuel combustion using syngas as a supplement to diesel leads to lower power output, exhaust gas temperature, volumetric efficiency and brake thermal efficiency with higher brake specific fuel consumption.

- The presence of carbon monoxide and methane in the syngas composition is very important for complete combustion due to their influence in increasing the heating value of syngas.

- The engine performance was affected by variations in syngas density and heating value more than by the engine speed.

- Composition C could be considered as the perfect choice to run the engine compared to other compositions at all engine speeds. The highest brake power output with the operation of the engine using Composition $\mathrm{C}$ was produced at the lowest brake specific fuel consumption and a high amount of diesel was replaced without penalties.

- The density of syngas plays a very important role in operating the engine while maintaining the lowest diesel consumption (high diesel replacement ratio). So a maximum diesel replacement of $74.2 \%$ was recorded for Composition $\mathrm{C}$ at an engine speed of $1200 \mathrm{rpm}$.

- Diesel replacement of up to $74.2 \%$ in dual-fuel mode was possible with the use of Composition $\mathrm{C}$ producing the highest power output, lowest BSFC, and highest brake thermal efficiency compared with other compositions.

- A diesel replacement of up to $51.1 \%$ in dual-fuel mode was possible with the use of Composition B at 1200 rpm showing the lowest exhaust gas temperature.

\section{ACKNOWLEGMENTS}

The author would like to acknowledge Universiti Teknologi PETRONAS (UTP) for providing support and laboratory facilities. The research for this paper was financially supported by ERGS fund, cost center: 0153AB-I13.

\section{REFERENCES}

[1] Hagos FY, Aziz ARA, Sulaiman SA. Trends of syngas as a fuel in internal combustion engines. Advances in Mechanical Engineering. 2014;2014: 1-10.

[2] Nayak C, Pattanaik BP, Nayak SK. Effect of preheated jatropha oil and jatropha oil methyl ester with producer gas on diesel engine performance. International Journal of Automotive and Mechanical Engineering. 2014;9:1709-22.

[3] Vashist D, Ahmad M. Statistical analysis of diesel engine performance for castor and jatropha biodiesel-blended fuel. International Journal of Automotive and Mechanical Engineering. 2014;10:2155-69.

[4] Yusaf T, Hamawand I, Baker P, Najafi G. The effect of methanol-diesel blended ratio on CI engine performance. International Journal of Automotive and Mechanical Engineering. 2013;8:1385-95.

[5] Hamada KI, Rahman MM. Experimental study performance emissions small four stroke SI engine modern motorcycle. International Journal of Automotive and Mechanical Engineering. 2014;10:1852-65.

[6] Kamil M, Rahman MM, Bakar RA. Performance evaluation of external mixture formation strategy in hydrogen fueled engine. Journal of Mechanical Engineering and Sciences. 2011;1:87-98. 
[7] Hairuddin AA, Wandel AP, Yusaf T. An introduction to a homogeneous charge compression ignition engine. Journal of Mechanical Engineering and Sciences. 2014; 7:1042-52.

[8] Sahoo B, Saha U, Sahoo N. Effect of load level on the performance of a dual fuel compression ignition engine operating on syngas fuels with varying h2/co content. Journal of Engineering for Gas Turbines and Power. 2011;133:122802.

[9] Karim GA. Combustion in gas-fueled compression ignition engines of the dual fuel type. Handbook of Combustion. 2003.

[10] Kapilan N, Ashok Babu TP, Reddy RP. Improvement of performance of dual fuel engine operated at part load. International Journal of Automotive and Mechanical Engineering. 2010;2:200-10.

[11] Ando Y, Yoshikawa K, Beck M, Endo H. Research and development of a lowBTU gas-driven engine for waste gasification and power generation. Energy. 2005;30:2206-18.

[12] Yamasaki Y, Tomatsu G, Nagata Y, Kaneko S. Development of a small size gas engine system with biomass gas (combustion characteristics of the wood chip pyrolysis gas). Combustion. 2007;2013:08-24.

[13] Krishna KS, Kumar KA. A study for the utilization of coffee husk in diesel engine by gasification. Proceedings of Biomass Gasification Technology, India. 1994.

[14] Mahgoub BKM, Sulaiman SA, Karim ZAA. Performance of a compression ignition engine fuelled by diesel and imitatecl syngas. Asian Journal of Scientific Research. 2013;6:456-66.

[15] Roy MM, Tomita E, Kawahara N, Harada Y, Sakane A. Effect of fuel injection parameters on engine performance and emissions of a supercharged producer gas-diesel dual fuel engine. Diesel Engine. 2009;2009:03-30.

[16] Ciferno JP, Marano JJ. Benchmarking biomass gasification technologies for fuels, chemicals and hydrogen production. US Department of Energy National Energy Technology Laboratory. 2002.

[17] Papagiannakis RG, Rakopoulos CD, Hountalas DT, Giakoumis EG. Study of the performance and exhaust emissions of a spark-ignited engine operating on syngas fuel. International Journal of Alternative Propulsion. 2007;1:190-215.

[18] Deshmukh SJ, Bhuyar LB, Thakre SB. Investigation on performance and emission characteristics of CI engine fuelled with producer gas and esters of hingan (Balanites) oil in dual fuel mode. International Journal of Mechanical, Industrial and Aerospace Engineering. 2008;2: 471-7.

[19] Duc PM, Wattanavichien K. Study on biogas premixed charge diesel dual fuelled engine. Energy Conversion and Management. 2007;48:2286-308.

[20] Shrivastava V, Jha AK, Wamankar AK, Murugan S. Performance and Emission Studies of a CI Engine Coupled with Gasifier Running in Dual Fuel Mode. Procedia Engineering. 2013;51:600-8.

[21] Noor MM, Wandel AP, Yusaf T. Air fuel ratio study for mixture of biogas and hydrogen on mild combustion. International Journal of Automotive and Mechanical Engineering. 2014;10:2144-54.

[22] Sahoo BB, Sahoo N, Saha UK. Effect of $\mathrm{H}_{2}: \mathrm{CO}$ ratio in syngas on the performance of a dual fuel diesel engine operation. Applied Thermal Engineering. 2011;49:139-46. 